\title{
Disease Screening of Three Breeding Populations of Adult Exhibition Budgerigars (Melopsittacus undulatus) in New Zealand Reveals a High Prevalence of a Novel Polyomavirus and Avian Malaria Infection
}

\author{
Hamish R. Baron, ${ }^{\mathrm{A}}$ Laryssa Howe, ${ }^{\mathrm{BE}}$ Arvind Varsani, ${ }^{\mathrm{CD}}$ and Robert J. T. Doneley ${ }^{\mathrm{A}}$ \\ ${ }^{\text {A }}$ School of Veterinary Science, University of Queensland, Gatton 4343, Queensland, Australia \\ ${ }^{\mathrm{B}}$ Department of Infectious Disease, Institute of Veterinary, Animal and Biomedical Sciences, Massey University, \\ Palmerston North 4442, New Zealand \\ ${ }^{\mathrm{C}}$ Electron Microscope Unit, Division of Medical Biochemistry, Department of Clinical Laboratory Sciences, University of Cape Town, \\ Observatory 7700 , South Africa \\ ${ }^{D}$ School of Biological Sciences and Biomolecular Interaction Centre, University of Canterbury, Private Bag 4800, Christchurch 8140, New Zealand
}

Received 2 July 2013; accepted 13 November 2013; published ahead of print 13 November 2013

\begin{abstract}
SUMMARY. Disease surveillance is vital to the management of New Zealand's endemic and threatened avian species. Three infectious agents that are potential threats to New Zealand's endemic birds include avian polyomavirus (APV), beak and feather disease virus (BFDV), and avian malaria. All three agents have been reported in New Zealand; however, possible reservoir populations have not been identified. In this communication, we report the first study of APV, BFDV, and avian malaria in introduced adult exhibition budgerigars (Melopsittacus undulatus) in New Zealand. Blood samples were collected from 90 living adult budgerigars from three breeding locations in the North Island of New Zealand. An overall APV prevalence of 22\% was determined using a broad-spectrum nested PCR that amplified the major capsid protein VP1 gene of polyomavirus. Phylogenetic analysis of the VP1 gene revealed a unique isolate of APV, which had a sequence divergence of $32 \%$ to previously reported budgerigar fledgling disease strains and $33 \%$ to the recently reported New Zealand finch isolate. All of the budgerigars sampled were found to be PCR negative for BFDV, and an overall prevalence of $30 \%$ was detected by PCR for avian malaria. Sequencing revealed the presence of ubiquitous malarial strains and also the potentially destructive Plasmodium relictum strain. The results of this study suggest that both APV and avian malaria are present in New Zealand adult budgerigars, and our study highlights the need for further studies to determine whether these pathogens in captive bird populations may be a threat or spill over into New Zealand's endemic and threatened avifauna and whether prevention and control methods need to be implemented.
\end{abstract}

RESUMEN. Un estudio de enfermedades de tres poblaciones reproductoras de periquitos australianos (Melopsittacus undulatus) de exhibición en Nueva Zelanda revela una alta prevalencia de una infección por un nuevo poliomavirus y por la malaria aviar.

La vigilancia de enfermedades es vital para el manejo de las especies aviares endémicas y amenazadas de Nueva Zelanda. Tres agentes infecciosos que son amenazas potenciales para las aves endémicas de Nueva Zelanda incluyen al poliomavirus aviar (APV), el virus de la enfermedad del pico y plumas (BFDV), y la malaria aviar. Los tres agentes se han reportado en Nueva Zelanda, sin embargo, no han sido identificadas poblaciones de posibles reservorios. En este artículo se presenta el primer estudio de poliomavirus aviar, del virus del pico y las plumas y de la malaria aviar en periquitos australianos (Melopsittacus undulatus) adultos de exhibición introducidos a Nueva Zelanda. Se recolectaron muestras de sangre de 90 periquitos adultos vivos de tres lugares de cría en la Isla Norte de Nueva Zelanda. Se determinó una prevalencia general de poliomavirus aviar de $22 \%$ utilizando un método de PCR anidado que amplifica el gene de la proteína principal de la cápside VP1 del poliomavirus. El análisis filogenético del gene VP1 reveló un aislamiento único de poliomavirus, que tenía una divergencia de 32\% en su secuencia en comparación con las cepas previamente asociadas con la enfermedad de la muda francesa de los periquitos (budgerigar fledgling disease) y de un $33 \%$ con un aislamiento de pinzón de Nueva Zelanda reportado recientemente. Todos los periquitos muestreados resultaron ser negativos por PCR para la enfermedad del pico y las plumas, y se detectó una prevalencia general del 30\% por PCR para la malaria aviar. La secuenciación reveló la presencia de cepas de malaria ubicuas y de una cepa de Plasmodium relictum que es potencialmente destructiva. Los resultados de este estudio sugieren que tanto poliomavirus aviar y la malaria aviar están presentes en periquitos australianos adultos de Nueva Zelanda y ponen de manifiesto la necesidad de realizar más estudios para determinar si estos patógenos presentes en poblaciones de aves en cautiverio pueden ser una amenaza o puedan extenderse a las especies endémicas y fauna aviar amenazada de Nueva Zelanda y si se requieren aplicar métodos de prevención y control.

Key words: avian polyomavirus, budgerigar fledgling disease, New Zealand, avian malaria, plasmodium, beak and feather disease virus

Abbreviations: $\mathrm{APV}=$ avian polyomavirus; $\mathrm{BFDV}=\mathrm{beak}$ and feather disease virus; $\mathrm{CaPyV}=$ canary polyomavirus; $\mathrm{CPyV}=$ crow polyomavirus; $\mathrm{FPyV}=$ finch polyomavirus; $\mathrm{GHPV}=$ goose hemorrhagic polyomavirus; $\mathrm{SDT}=$ species demarcation tool; $\mathrm{WCC}=$ white cell count

Polyomaviruses are members of the Polyomavirus genus with nonenveloped virons encapsidating circular double-stranded DNA genome (28). These viruses have been shown to infect a wide range of avian and mammalian host species, although most have been

${ }^{\mathrm{E}}$ Corresponding author. E-mail: L.Howe@massey.ac.nz shown to be species specific (26). Avian polyomavirus (APV) was first discovered in 1981 (10) and is known to be the causative agent in budgerigar fledgling disease (33) as well as causing fatal disease in a variety of other species $(5,15,16,27,30)$. APV affects a range of avian hosts; however, the clinical presentation, distribution of lesions, and epidemiological effects of the virus on a population vary markedly between susceptible species $(5,10,13)$. Polyomavirus 
infection in birds is an acute inflammatory disease and can have a mortality rate of up to $100 \%$ in fledglings (28). To date, there are five known polyomaviruses of birds; APV, goose hemorrhagic polyomavirus (GHPV), finch polyomavirus (FPyV), crow polyomavirus $(\mathrm{CPyV})$, and canary polyomavirus (CaPyV) (20).

In budgerigars (Melopsittacus undulatus), the severity of disease caused by APV depends on the age and condition of the bird when exposure occurs. Clinical presentation includes acute death at 10 15 days old with no clinical signs, while other fledglings may develop abdominal distension, subcutaneous hemorrhage, ataxia, hydropericardium, ascites, and feather abnormalities known as "French molt" $(10,22,28,33,37,47)$. APV has also been associated with decreased hatchability and embryonic death (17). As a result of several devastating outbreaks in captive birds in North America, Australia, and Europe, APV is now a recognized globally as an avian pathogen (43). A small serological survey in 2002 (25) and a recent confirmed report of APV isolated by PCR from a captive finch (1) suggests that this virus is present in New Zealand; however, the prevalence in caged and wild birds is unknown.

A second common viral disease causing feather loss in psittacine birds is beak and feather disease virus (BFDV), a member of the family Circoviridae. The virus is highly infectious, and all psittacine birds are potentially susceptible to BFDV infections, which cause progressive feather loss, dystrophy, and beak deformities $(40,44)$. The virus was first described in psittacine birds in the Australia (36) and is now the most important infectious disease affecting psittacine species. The virus has been detected in New Zealand native parrots (Cyanoramphus spp. [two species] and Platycercus eximius) $(18,19,32,34)$ and is considered to be the cause of high mortality rates in the South African cape parrot (Poicephalus robustus) and lovebirds (Agapornis spp.) (53).

Finally, avian malaria is a mosquito-borne disease caused by intracellular parasites in the order Haemosporida, genus Plasmodium. Species of the genus Plasmodium have a cosmopolitan distribution and can infect nearly all avian taxa (51). Passerines are known to be hosts to the largest number of haemosporidian parasites (51). For example, Plasmodium relictum has a global distribution and has long been known to infect blackbirds (Turdus merula) and other introduced birds in New Zealand (24,50), which are commonly observed as asymptomatic carriers of avian malaria, showing a low mortality and mainly chronic parasitaemia of malaria (50). Recent studies in New Zealand have shown Plasmodium spp. are able to infect a wide range of endemic avifauna and have been diagnosed as causing death in threatened species such as dotterel (Charadrius obscurus) (2), South Island saddleback (Philesturnus carunculatus carunculatus) (4), mohua (Mohoua ochrocephala) (3), hihi (Notiomystis cincta) (3), brown kiwi (Apteryx mantelli) (7), and great spotted kiwi (Apteryx haastii) (24).

Although they are not notifiable diseases in New Zealand, APV, BFDV, and Plasmodium spp. are still considered "diseases of concern" in conservation management (54); however, detailed information on the three diseases is limited, particularly within the captive bird populations. The last legal importation of budgerigars into New Zealand occurred in 1996; the birds are now maintained as a "closed population." Thus, these birds provide a unique opportunity to identify possible pathogens within the breeding populations and their role as disease reservoirs for New Zealand's threatened endemic avifauna. In this preliminary study, we report the identification of a novel polyomavirus possibly associated with observed feather abnormalities and four different avian malaria strains infecting adult exhibition budgerigars in three breeding collections in the North Island of New Zealand.

\section{MATERIALS AND METHODS}

Sample collection. Thirty budgerigars were sampled from each of three breeding aviaries in the North Island of New Zealand in July 2012. We selected aviaries where budgerigars were bred and where feather abnormalities had occurred within the last 3 yr. All three aviaries had exchanged and exhibited birds at the same shows in the last $2 \mathrm{yr}$.

Bird captures were carried out using a 2-mm woven nylon hand bird net with a $200-\mathrm{mm}$ padded wire frame on a $500-\mathrm{mm}$ polyester handle. Band numbers were recorded for every sampled bird, and the birds were examined for feather condition, evidence of skin lesions, external injury, and general body condition. Where possible, birds with feather abnormalities were selected. Feathers were regarded as abnormal if on physical examination, any feathers were missing, dystrophic, or otherwise imperfect. Once appropriately restrained in hand, a blood sample of $0.1 \mathrm{ml}$ was collected from the jugular vein of each bird using $0.33-\mathrm{mm}(29 \mathrm{G})$ needle on a BD Ultra-Fine ${ }^{\mathrm{TM}} 0.5-\mathrm{ml}$ insulin syringe (Becton, Dickson and Company, Franklin Lakes, NJ) following protocols described by Brown (11). Blood was spotted onto two pieces of grade one filter paper (Whatman ${ }^{\mathrm{TM}}$; GE Healthcare, Little Chalfont, Buckinghamshire, UK) and dried before being placed into a mini snaplock bag. To avoid cross contamination between samples, gloves were disposed of between each bird, and the capture net was soaked in a disinfectant solution (VirkonS, Dupont, Wilmington, DE) for $10 \mathrm{~min}$ between samples. Samples were stored at room temperature until processed.

Blood smear preparation and microscopy. A single drop of blood from each bird sampled was used to produce a thin blood smear that was air-dried, placed in a slide holder at the time of collection, and subsequently stained with Diff-Quick. Each blood smear was examined to determine the differential white cell count (WCC), smears were examined under a light microscope for a minimum of $15 \mathrm{~min}$, initially at low power $(\times 400)$ for 10 random fields of single layered red blood cells. All white cells were counted and recorded; the sum of white cells from all 10 fields was divided by 5 to give an estimated mean differential white cell count. Smears were then examined at $\times 1000$ under oil immersion and a breakdown of the white cell population was recorded by scanning each slide until 100 white cells were observed.

Molecular detection of APV. DNA was isolated from each sample using the DNeasy Blood and Tissue Kit (Qiagen, Valencia, CA) following the manufacturer's protocol for nucleated whole blood. The presence of the polyomavirus major capsid protein VP1 gene was identified using a broad-spectrum nested PCR as described by Johne et al. (26). To confirm successful amplification, $10 \mu \mathrm{l}$ of the final PCR product was run on a $1.5 \%$ agarose gel containing ethidium bromide prior to purification and sequencing. A known polyomavirus positive tissue sample from a Gouldian finch (1), confirmed by sequencing was used as a positive control, and water blanks were included as negative controls.

Two positive PCR amplicon samples from each aviary were purified using a PureLink PCR purification kit (Invitrogen, Carlsbad, CA) and subjected to automatic dye-terminator cycle sequencing with BigDye ${ }^{\mathrm{TM}}$ Terminator Version 3.1 Ready Reaction Cycle Sequencing kit and the ABI3730 Genetic Analyzer (Applied Biosystems Inc., Foster City, CA) to confirm genomic sequence using both the forward and reverse primers. The polyomavirus isolate sequences obtained were compared by NCBI Blast to other published sequences available from GenBank.

Phylogenetic analysis of polyomavirus isolates. The VP1 gene from one sequence of bovine papillomavirus (bovine PapV) and 19 representative polyomaviruses detected in different bird and mammal species submitted to GenBank, three polyomaviruses isolated in this study (NZBPyV3, 90, 78), and the outgroup bovine papillomavirus were trimmed to the same length (282 base pairs) using Geneious ${ }^{\text {TM }}$ (Biomatters, Auckland, New Zealand) and aligned using Clustal W (23) with gaps ignored. A Bayesian phylogenetic tree was generated in MrBayes version 3.1 (46) using general time-reversible model including invariable sites $(\mathrm{GTR}+\mathrm{I})$ as a nucleotide substitution model. The Bayesian phylogeny was obtained using one cold and three hot Monte Carlo Markov chains, which were sampled every 1000 generations over 
Table 1. Summary of polyomavirus PCR results and comparison with birds displaying normal feathers and abnormalities.

\begin{tabular}{|c|c|c|c|c|c|c|c|}
\hline & \multicolumn{2}{|c|}{ Property 1} & \multicolumn{2}{|c|}{ Property 2} & \multicolumn{2}{|c|}{ Property 3} & \multirow[b]{2}{*}{ Total } \\
\hline & Normal $^{\mathrm{A}}$ & Abnormal $^{\mathrm{B}}$ & Normal & Abnormal & Normal & Abnormal & \\
\hline Number of samples & 9 & 21 & 0 & 30 & 21 & 9 & 90 \\
\hline Prevalence (\%) & 22.2 & 28.6 & 0 & 26.7 & 14.3 & 11.1 & 22.2 \\
\hline $95 \%$ confidence interval & $2.8-60.0$ & $11.3-52.2$ & 0 & $12.3-45.9$ & $3.0-36.3$ & $0.3-48.2$ & $14.1-32.2$ \\
\hline
\end{tabular}

${ }^{\mathrm{A}}$ Number of birds with normal feather plumage.

${ }^{\mathrm{B}} \mathrm{Number}$ of birds with feather abnormalities.

1.5 million generations. Of these trees, $25 \%$ were discarded as burn-in material. The remaining trees were used to construct a majority consensus tree. Bootstrap percentages from the Bayesian analysis were added to the tree at the appropriate nodes. Pairwise identities between and within the different strains were calculated with species demarcation tool (SDT) v1.0.

Open reading frames were identified, and amino acid sequences were deduced from the nucleotide sequences from five previously described avian polyomaviruses (CaPyV GenBank GU345044, APV GenBank AF241168, FPyV GenBank DQ192571, GHPV GenBank AY140894, CPyV GenBank DQ192570) and an isolate from this study (NZBPyV3) using Geneious (Biomatters) and aligned using Clustal W (23). The sequence divergence between and within the different strains was calculated using SDT v1.0.

Molecular detection of BFDV. Total DNA was extracted from blood and feather budgerigar samples using iGenomic blood DNA extraction kit (Intron Biotechnology, Sangdaewon-Dong, South Korea) according to the manufacturer's instructions. A BFDV screen was set up using primers that target a $\sim 600$-bp region of the replication associated gene (5'-TTA ACA ACC CTA CAG ACG GCG A-3' and 5'-GGC GGA GCA TCT CGC AAT AAG-3') (45). In brief, $4 \mu \mathrm{l}$ of the total extracted DNA was used in a PCR reaction with the above primers and KAPA Blood PCR Kit Mix B (KAPA Biosystems, Woburn, MA) using the following protocol: an initial 5-min denaturation step, followed by 25 cycles of $94 \mathrm{C}$ for $30 \mathrm{sec}, 56 \mathrm{C}$ for $30 \mathrm{sec}$, and $72 \mathrm{C}$ for $45 \mathrm{sec}$, with a final extension step of $72 \mathrm{C}$ for $1 \mathrm{~min}$ and cooling to $4 \mathrm{C}$ for $10 \mathrm{~min}$ for renaturation. The amplicons were resolved on a $1 \%$ agarose gel stained with SYBR ${ }^{\circledR}$ Safe DNA stain.

Molecular detection of Avian Malaria. DNA was extracted from whole blood as described for the detection of APV. The presence of the cytochrome $b$ gene of Plasmodium spp. was identified using a nested PCR and the nested primer sets HaemNF1/HaemNR3 and HaemF/HaemR2 as described by Hellgren et al. (21). To confirm a successful amplification, $10 \mu \mathrm{l}$ of the final PCR product was run on a $1.5 \%$ agarose gel containing ethidium bromide prior to purification and sequencing. A known Plasmodium spp.-positive blood sample was used as a positive control, and water blanks were included as negative controls. Three representative Plasmodium spp.-positive PCR amplicon samples from each property were purified and subjected to sequencing as described above. Chromatograms were examined for conspicuous overlapping peaks suggestive of Plasmodium spp. coinfection. The Plasmodium isolate sequences obtained were compared with the MalAvi database (9) and by NCBI Blast with those other published sequences available from GenBank.

Animal Ethics. Samples were obtained under permission of the collection owners and the University of Queensland Animal Ethics Committee (Production and Companion Animal) permit number SVS/ $106 / 12$.

Statistics. The relationships between APV and avian malaria were examined, as was each of these and their relationship with common disease indicators in budgerigars. Disease indicators examined included endoparasite and ectoparasite load, mean differential white cell count, age, and feather abnormalities. A combination of Pearson's chi-squared test, Wilcoxon analysis, and two sample $t$-tests were used to determine statistical significance for each of the relationships. All analyses were carried out using the $\mathrm{R}$ programming language for statistical computing (39). Tests were carried out at the 5\% level of significance. Specifically, the relationship between APV and mean differential WCC was examined using a $\log _{e}$ transformation of WCC to normalize the data set and a two sample $t$-test. Results are presented exponentiated back into the original units $\left(\times 10^{9}\right.$ cells/L) and refer to group medians, rather than means, as a consequence of this transformation.

\section{RESULTS}

Clinical and molecular evidence of polyomavirus infection. Sixty-six percent (60/90) of the sampled birds had clinical evidence of flight feather or tail abnormalities; this included primary flight feather loss ranging from one flight feather unilaterally, to all flight feathers bilaterally. Tail feather abnormalities included primary and secondary feather loss or feathers that remained ensheathed. The remainder of the birds sampled displayed normal feather characteristics.

Twenty-two percent (20/90) of blood samples were found to be positive for the polyomavirus VP1 gene (Table 1). Each of the properties sampled had birds with polyomavirus positive blood samples. Among the birds with normal plumage, the prevalence ranged between 14.3 and $26.7 \%$ (Table 1). Birds with feather abnormalities had a prevalence of between 11.1 and $28.6 \%$ (Table 1). There was no statistical difference between the detected polyomavirus prevalence in the birds displaying normal plumage versus abnormal plumage $(P=0.37)$. Of the common disease states examined, there was a strong relationship between infection with APV and an increased estimated differential mean WCC. Median WCC was $8.0(95 \%$ confidence interval $[\mathrm{CI}]=6.7-9.6) \times 10^{9} / \mathrm{L}$ in polyomavirus positive birds compared with 15.4 (95\% CI $=10.7$ 22.3) $\times 10^{9} / \mathrm{L}$ in noninfected birds, $P=0.001$. We estimate the median white cell count for birds infected with APV to be 1.93 (95\% CI $=1.30-2.86)$ times higher (or 93\% larger) than birds without the virus. These findings indicate a leucocytosis, which is frequently a sign of an inflammatory response, most commonly the result of infection, but also observed in certain parasitic infections.

BLAST analysis of six isolates showed a range of sequence homology (69-81\%) with budgerigar fledgling disease polyomavirus APV strains (GenBank GU452537, DQ304718, AF241168, AB453160), 71\% homology with goose hemorrhagic (GHPV) and nonhemorrhagic polyomavirus strains (GenBank HQ681903, AF226991), and 72\% homology with a New Zealand finch polyomavirus isolate (NZFPyV1, GenBank JX425365). All other wellcharacterized polyomavirus strains, including human (GenBank JX262162), bat (GenBank JQ958889), and northern fur seal (GenBank JQ031271) isolates, had a sequence homology ranging between 67 and 91\%. In most cases, high sequence homology with nonavian polyomavirus strains only covered $30 \%$ or less of the submitted sequence, whereas the polyomavirus strains aligned to 


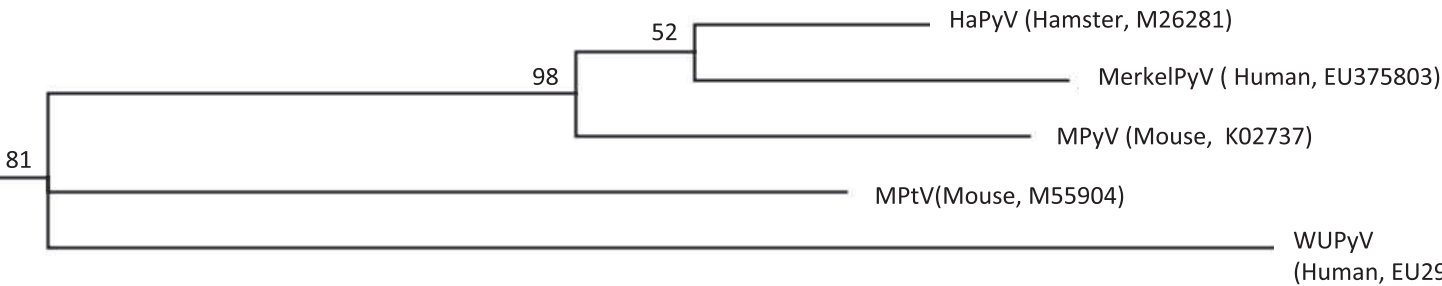
(Human, EU296475)

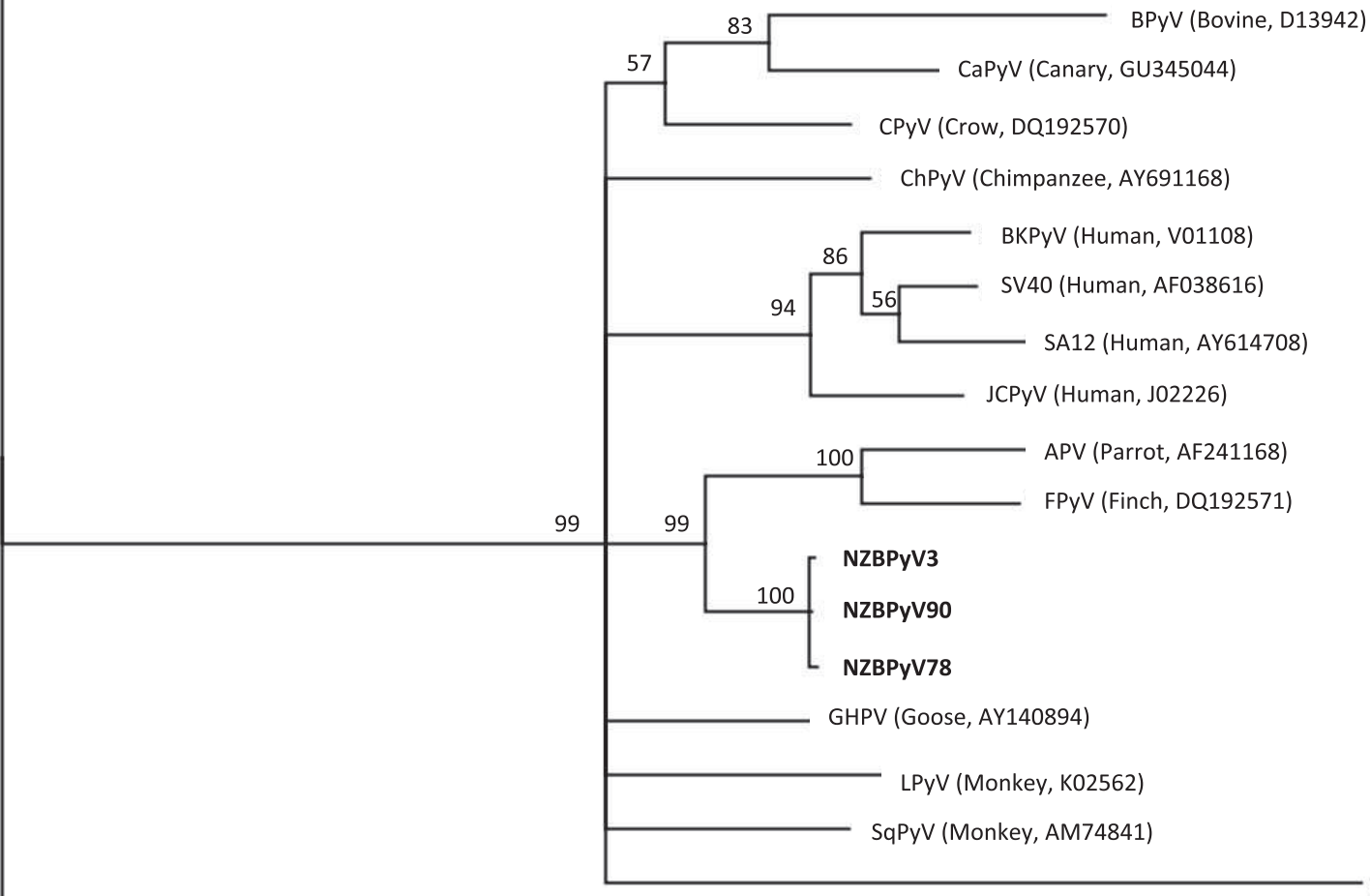

KiPyV (Human, EU358767)

Bovine PapV (NC001522)

Fig. 1. Phylogenetic analysis of polyomavirus isolated from exhibition budgerigars (Melopsittacus undulatus) in New Zealand. Bayesian analysis of a 282 nucleotide fragment of the VP1 gene from 1 sequence of bovine papillomavirus (bovine PapV) and 19 polyomaviruses detected in different bird and mammal species submitted to GenBank, and three representative polyomaviruses isolated in this study (in bold). The tree is rooted on a lineage of bovine papillomavirus. Numbers above the branches indicate bootstrap support based on 1000 replicates. Host species and GenBank accession numbers of the sequences are given after the abbreviated polyomavirus names.

$97 \%$ of the submitted sequence, suggesting that the New Zealand isolates were novel budgerigar strains and were tentatively designated NZ budgerigar polyomavirus (NZBPyV).

Phylogenetic analysis confirmed the novel nature of the NZBPyV isolates but did cluster them with the representative APV (GenBank AF241168) and FPyV (GenBank DQ192571) strains consistent with the avian host (Fig. 1). Sequence divergence analysis showed a $30 \%$ and $31 \%$ difference between the NZ isolates and the APV and FPyV strains, respectively, consistent with the BLAST results. A separate alignment of the partial VP1 sequence (89 amino acids) of the five known bird polyomaviruses and the NZ isolates were suggestive of a relatively high amino acid divergence (25.8-36\%), particularly in the H-I loop (Fig. 2).

Molecular detection of BFDV and avian malaria. None of the 90 individual samples tested were positive for BFDV; however, the prevalence of avian malaria varied between properties and ranged between $13 \%$ and $43 \%$ with an overall prevalence of $30 \%$ (Table 2). Twenty-six percent of birds positive for Plasmodium spp. DNA were also positive for APV, although this relationship was not statistically significant $(P=0.6701)$. Sequencing of three representative positive samples from each property revealed differences in the Plasmodium spp. infecting the birds (Table 2). Two of three isolates from property 1 had $100 \%$ sequence homology to the reference strain of Plasmodium (Huffia) elongatum GRW6 (GenBank DQ368381). The third isolate had $99 \%$ sequence homology to the reference strain of Plasmodium (Haemamoeba) relictum GRW4 (GenBank AY099041). In addition, all three isolates sequenced from property 2 and two isolates from property 3 displayed $100 \%$ sequence homology to Plasmodium spp. lineage AFTRU5 (GenBank DQ847263), and the final isolate from property 3 had $100 \%$ sequence homology with P. (Novyella) spp. lineage SYATO5 (GenBank DQ847271). No evidence of mixed infections (conspicuous overlapping peaks) was observed in the isolates sequenced.

\section{DISCUSSION}

Disease surveillance is vital to the management of New Zealand's endemic and threatened avian species. In some instances, potential pathogens can infect bird species without causing disease, while in others the infection results in high levels of mortality. In addition, subclinical disease in some hosts, particularly introduced species, 
Consensus

CPyV

GHPV

CaPyV

APV

FPyV

NZBPyV ENGVGPLCKGDGLYLSAADI本GXYXDQYSQAQYXRGLPRYFSVTLRKRVVXNPYPVSXLLXSLFNXLMPRMQGQPMXGKDAQVEEVRVYE

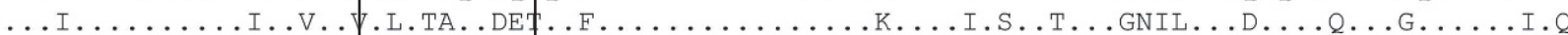

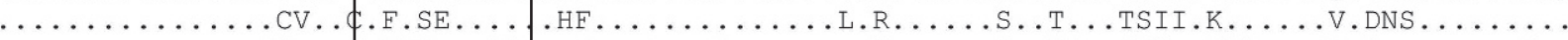

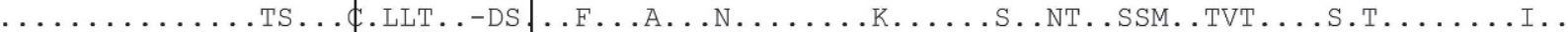

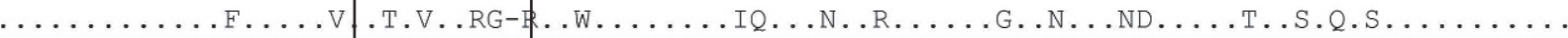

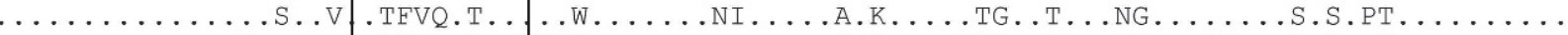

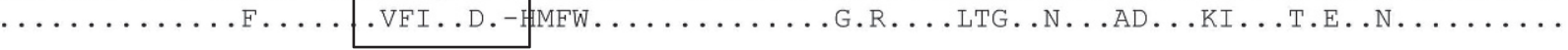

Fig. 2. Alignment of the deduced amino acid sequences of VP1 from the six known bird polyomaviruses. The 239-328 amino acid region of the VP1 is shown and identical positions with the sequence are indicated by a dot. The VP1 HI loop is boxed (according to Liddington et al.) (31).

may provide a reservoir population for subsequent infection of naive endemic avifauna. Three infectious agents that are potential threats to New Zealand's endemic birds include APV, BFDV, and avian malaria. All three agents have been reported in New Zealand; however, the possible reservoir populations have not been identified for APV and BFDV.

As the first study examining budgerigars as a possible reservoir population, the implications are far reaching. Not only have we confirmed APV is present in at least some New Zealand budgerigar aviaries, but the identification of a novel virus suggests that more detailed phylogenetic and phylogeographical studies are needed to improve our understanding of APV in birds in New Zealand. Further investigation is warranted into the presence and effects of APV in captive populations of native New Zealand psittacine parrots including kakariki (Cyanoraphus sp.) and zoological collections of kea (Nestor notabilis) and kaka (Nestor meridionalis).

Most budgerigars become infected with APV as nestlings, and survivors shed the virus in their droppings for up to 6 mo postinfection (38). The budgerigars sampled in this study included fledglings and adults between 6 mo and $6 \mathrm{yr}$ old, with PCR positive birds between 9 mo and 5 yr 8 mo old, which suggest that this novel strain of APV is enzootic in all three aviaries sampled. A study by Ritchie et al. (42) suggests that budgerigars are the only avian species that remain persistently infected and shed the virus throughout life. However, another study suggested that APV can be eliminated from aviaries by resting seropositive adult birds from breeding 7 mo prior to breeding, leading to the production of seronegative, clinically normal budgerigar chicks (38).

Our study suggests that there may be an association with polyomavirus and leukocytosis. Interestingly, there was no statistical support for the association between APV and avian malaria infection or feather abnormalities. The latter may have been the result of a stringent selection criterion for feather abnormalities, in that any abnormal, missing, or dystrophic feathers meant the bird was considered abnormally feathered for analysis purposes. Including naturally molting birds missing flight or tail feathers is therefore a potential source of bias, but by the nature of the selection criteria, this could not have been avoided without a complicated feather grading system. Importantly, BFDV can be excluded as a potential source of feather loss in the budgerigars sampled, and the $0 \%(95 \%$
$\mathrm{CI}=0.0-4.0 \%)$ prevalence in birds selected for clinical feather abnormalities makes it unlikely BFDV is a major viral pathogen affecting budgerigar collections in New Zealand.

Having established the presence of APV in New Zealand, it is important to now attempt to better understand its epidemiology and, more specifically, the possible risks associated with APV to native New Zealand psittacine birds. Most members of the Polyomaviridae family are limited in their host range. In contrast, APV appears to be infective in a wide variety of Psittaciformes, Passeriformes, and gallinaceous birds (41). The wide variety of clinical manifestations previously recorded between species and the potential for dissemination into avian species outside of the budgerigar aviaries in which it appears enzootic suggests that this novel polyomavirus poses an unknown, but potentially significant risk to the native avifauna population in New Zealand. Combined with the lack of investigation into the potential effects on a naive population and the unknown susceptibility of New Zealand's native bird species, this suggests that APV should be an area of high importance with regard to maintaining and conserving $\mathrm{New}$ Zealand's native and endemic avifauna.

An example of how rapidly these introduced diseases can spread is avian malaria. Up until $50 \mathrm{yr}$ ago, Plasmodium infections in native and endemic New Zealand birds were considered uncommon (29). However, over the last decade avian malaria has become increasingly common and has caused mortality in several threatened species, including the mohua ( $M$. ochrocephala) (3), North Island brown kiwi (A. mantelli) (24), and South Island saddleback ( $P$. carunculatus carunculatus) (4). The prevalence of Plasmodium in introduced passerines ranges between $7 \%$ and $100 \%$ depending on region, time of year, and avian species sampled $(48,50)$. In native passerines, the prevalence of chronic infections has been recorded as 10\%-13\% in North Island saddleback (Philesturnus carunculatus) and bellbirds (Athornis melanura), respectively $(6,12)$. Phylogenetic analysis of Plasmodium species present in New Zealand native and endemic birds includes the internationally ubiquitous $P$. (Huffia) elongatum and the potentially devastating $P$. (Haemamoeba) relictum $(12,14,24)$, both of which were isolated in this study.

This study found at least four different strains of Plasmodium circulating in the budgerigar populations of New Zealand's North Island. The high incidence of infection in the birds sampled suggests

Table 2. Summary of BFDV and avian malaria PCR results and Plasmodium spp. detected by sequencing.

\begin{tabular}{|c|c|c|c|c|c|}
\hline $\begin{array}{l}\text { Property } \\
\text { number }\end{array}$ & BFDV positive $(\%)$ & $\begin{array}{l}\text { Plasmodium } \mathrm{PCR} \\
\text { positive }(\%)\end{array}$ & $\begin{array}{c}\text { No. of Plasmodium positive } \\
\text { birds coinfected with APV (\%) }\end{array}$ & Plasmodium lineages identified & GenBank no. \\
\hline 1 & $0 / 30(0)$ & $4 / 30(13)$ & $2 / 4(50)$ & $\begin{array}{l}\text { P. (Huffia) elongatum GRW6 } \\
\text { P. (Haemamoeba }) \text { relicitum GRW4 }\end{array}$ & $\begin{array}{l}\text { DQ368381 } \\
\text { AY099041 }\end{array}$ \\
\hline 3 & $0 / 30(0)$ & $13 / 30(43)$ & $3 / 13(23)$ & $\begin{array}{l}\text { P. }(\text { Novyella }) \text { spp. SYATO5 } \\
\text { Plasmodium spp. AFTRU5 }\end{array}$ & $\begin{array}{l}\text { DQ847271 } \\
\text { DQ847263 }\end{array}$ \\
\hline Total & $0 / 90(0)$ & $27 / 90(30)$ & $7 / 27(26)$ & & \\
\hline
\end{tabular}


that the infectious cycle is well established in these collections. Plasmodium (Huffia) elongatum has been reported in a wide range of avian orders but particularly Passeriformes, which are thought to act as reservoirs (51). Similarly, both Plasmodium spp. AFTRU5 and P. (Novyella) spp. SYATO5 are considered ubiquitous in most Passeriformes in New Zealand, with P. (Novyella) spp. SYATO5 showing a predilection for the blackbird ( $T$. merula) (24). It is important to note that an isolate of $P$. (Haemamoeba) relictum GRW4 was detected in one of the collections. This particular strain of Plasmodium is widespread throughout Europe and tropical regions of Africa and known to be a host generalist with a cosmopolitan distribution (51). Lineages GRW4 and SGS1 have been shown to infect multiple African and European avian host species, which suggests that members of the $P$. (Haemamoeba) relictum subgenera undergo relatively frequent host shifts $(21,52)$. Notably, the ability to host shift may have contributed to the decline and extinction of bird species in Hawaii after the introduction of lineage GRW4 (8). Plasmodium (Haemamoeba) relictum has been shown experimentally to infect various passerines with differing disease severity (35). While there was no relationship between common disease indicators and Plasmodium spp. infection in the budgerigars sampled, further longitudinal modeling is warranted to determine the significance and pathogenicity of the various strains in budgerigars. Budgerigar collections may also act as a point source reservoir for infection of those birds that frequent the environment in which the budgerigars live. These wild birds have the potential to then disseminate Plasmodium spp. large distances either through migration events or normal home range movements, which, assuming there is a suitable vector in the environment, will facilitate spread to naive, native populations.

This is the first study to demonstrate the presence of APV and avian malaria in breeding populations of New Zealand exhibition budgerigars. Thus, a thorough examination of the interaction between these diseases and the budgerigar population will increase our understanding of the prevalence and potential impact avian malaria may be having on our endangered and threatened avifauna. An increasing awareness and regular monitoring programs of introduced and endemic avian species will help to develop appropriate management strategies for conservation programs to minimize the impact of these diseases in New Zealand.

\section{REFERENCES}

1. Alley, M., I. Rasiah, E. A. Lee, L. Howe, and B. D. Gartrell. Avian polyomaviurs identified in nestling finches in New Zealand. N. Z. Vet. J. 61:359-361. 2013.

2. Alley, M. R. Avian wildlife diseases in New Zealand: current issues and achievements. N. Z. Vet. J. 50:118. 2002.

3. Alley, M. R., R. A. Fairley, D. G. Martin, L. Howe, and T. Atkinson. An outbreak of avian malaria in captive yellowheads/mohua (Mohoua ochrocephala). N. Z. Vet. J. 56:247. 2008.

4. Alley, M. R., K. A. Hale, W. Cash, H. J. Ha, and L. Howe. Concurrent avian malaria and avipox virus infection in translocated South Island saddlebacks (Philesturnus carunculatus carunculatus). N. Z. Vet. J. 58:218-223. 2010.

5. Arroube, A. S., M. Y. Halami, R. Johne, and G. M. Dorrestein. Mortality due to polyomavirus infection in two nightjars (Caprimulgus europaeus). J. Avian Med. Surg. 23:136-140. 2009.

6. Baillie, S. M., D. Gudex-Cross, R. K. Barraclough, W. Blanchard, and D. H. Brunton. Patterns in avian malaria at founder and source populations of an endemic New Zealand passerine. Parasitol. Res. 111:2077-2089. 2012.

7. Banda, M., L. Howe, B. Gartrekk, K. McInnes, S. Hunter, and N. P. French. A cluster of avian malaria cases in a kiwi management program. N. Z. Vet. J. 61:121-126. 2012.
8. Beadell, J. S., F. Ishtiaq, R. Covas, M. Melo, B. H. Warren, C. T. Atkinson, S. Bensch, G. R. Graves, Y. V. Jhala, M. A. Peirce, A. R. Rahmani, D. M. Fonseca, and R. C. Fleischer. Global phylogeographic limits of Hawaii's avian malaria. Proc. Biol. Sci. 273:2935-2944. 2006.

9. Bensch, S., O. Hellgren, and J. Pérez-Tris. MalAvi: a public database of malaria parasites and related haemosporidians in avian hosts based on mitochondrial cytochrome b lineages. Mol. Ecol. Resour. 9:1353. 2009.

10. Bernier, G., M. Morin, and G. Marsolais. A generalized inclusion body disease in the budgerigar (Melopsittacus undulatus) caused by a papovavirus-like agent. Avian Dis. 25:1083-1092. 1981.

11. Brown, C. Venipuncture in psittacine birds. Lab. Anim. 36:21-22. 2007

12. Castro, I., L. Howe, D. M. Tompkins, R. K. Barraclough, and D. Slaney. Presence and seasonal prevalence of plasmodium spp. in a rare endemic New Zealand passerine (Tieke or Saddleback, Philesturnus carunculatus). J. Wildlife Dis. 47:860-867. 2011.

13. Deb, A., U. Foldenauer, R. J. Borjal, W. J. Streich, C. Lüken, R. Johne, H. Müller, and S. Hammer. A longitudinal study on avian polyomavirus-specific antibodies in captive Spix's Macaws (Cyanopsitta spixii). J. Avian Med. Surg. 24:192-198. 2010.

14. Ewen, J. G., S. Bensch, T. M. Blackburn, C. Bonneaud, R. Brown, P. Cassey, R. H. Clarke, J. Pérez-Tris, and R. Ostfeld. Establishment of exotic parasites: the origins and characteristics of an avian malaria community in an isolated island avifauna. Ecol. Lett. 15:1112-1119. 2012.

15. Forshaw, D., S. L. Wylie, and D. A. Pass. Infection with a virus resembling papovavirus in Gouldian finches (Erythrura gouldiae). Aust. Vet. J. 65:26-28. 1988.

16. Garcia, A., K. S. Latimer, F. D. Niagro, T. M. Norton, R. P. Campagnoli, B. G. Harmon, E. W. Howerth, and B. W. Ritchie. Diagnosis of polyomavirus infection in seedcrackers (Pyrenestes sp.) and blue bills (Spermophaga haematina) using DNA in situ hybridization. Avian Pathol. 23:525-537. 1994.

17. Gough, J. F. Outbreaks of budgerigar fledgling disease in three aviaries in Ontario. Can. Vet. J. 30:672-674. 1989.

18. Ha, H. J., M. R. Alley, J. I. Cahill, L. Howe, and B. D. Gartrell. The prevalence of psittacine beak and feather disease virus infection in native parrots in New Zealand. N. Z. Vet. J. 57:50-52. 2009.

19. Ha, H. J., I. L. Anderson, M. R. Alley, B. P. Springett, and B. D. Gartrell. The prevalence of beak and feather disease virus infection in wild populations of parrots and cockatoos in New Zealand. N. Z. Vet. J. 55:235-238. 2007

20. Halami, M. Y., G. M. Dorrestein, P. Couteel, G. Heckel, H. Müller, and R. Johne. Whole-genome characterization of a novel polyomavirus detected in fatally diseased canary birds. J. Gen. Virol. 91:3016-3022. 2010.

21. Hellgren, O., A. Križanauskiene, G. Valkiūnas, and S. Bensch. Diversity and phylogeny of mitochondrial cytochrome b lineages from six morphospecies of avian Haemoproteus (Haemosporida: Haemoproteidae). J. Parasitol. 93:889-896. 2007.

22. Herder, V., A. Konig, F. Seehusen, and P. Wohlsein. Avian polyomavirus infection of a fledgling budgerigar (Melopsittacus undulatus) and differential diagnoses of viral inclusions in psittacine birds-case report and mini-review. Berl. Munch. Tierarztl. 124:209-216. 2011.

23. Higgins, D., J. Thompson, T. Gibson, J. D. Thompson, D. G. Higgins, and T. J. Gibson. ClustalW: improving the sensitivity of progressive multiple sequence alignment through sequence weighting, position-specific gap penalties, and weight matrix choice. Nucl. Acids Res. 22:4673-4680. 1994.

24. Howe, L., I. C. Castro, E. R. Schoener, S. Hunter, R. K. Barraclough, and M. R. Alley. Malaria parasites (Plasmodium spp.) infecting introduced, native and endemic New Zealand birds. Parasitol. Res. 110:913-923. 2012.

25. Jakob-Hoff, R. Report to the Ministry of Agriculture and Forestry Biosecurity Authority on the avian animal health project. In: Wildlife Health and Research Centre, Auckland Zoo, Private bag, Grey Lynn, Auckland. 2003.

26. Johne, R., D. Enderlein, H. Nieper, and H. Müller. Novel polyomavirus detected in the feces of a chimpanzee by nested broadspectrum PCR. J. Virol. 79:3883-3887. 2005.

27. Johne, R., and H. Müller. Avian polyomavirus in wild birds: genome analysis of isolates from Falconiformes and Psittaciformes. Arch. Virol 143:1501-1512. 1998. 
28. Krautwald, M. E., H. Muller, and E. F. Kaleta. Polyomavirus infection in budgerigars (Melopsittacus undulatus) — clinical and etiological studies. J. Vet. Med. 36:459-467. 1989.

29. Laird, M. Some blood parasites of New Zealand Birds. In: Zoology publications. Victoria University College, Wellington. pp. 1-20. 1950.

30. Latimer, K. S., F. D. Niagro, W. L. Steffens, B. W. Ritchie, and R. P. Campagnoli. Polyomavirus encephalopathy in a Ducorps' cockatoo (Cacatua ducorpsii) with psittacine beak and feather disease. J. Vet. Diagn. Invest. 8:291-295. 1996.

31. Liddington, R. C., Y. Yan, J. Moulai, R. Sahli, T. L. Benjamin, and S. C. Harrison. Structure of simian virus 40 at $3.8 \AA$ resolution. Nature 354:278-284. 1991.

32. Massaro, M., L. Ortiz-Catedral, L. Julian, J. A. Galbraith, B. Kurenbach, J. Kearvell, J. Kemp, J. van Hal, S. Elkington, G. Taylor, T. Greene, J. van de Wetering, M. van de Wetering, M. Pryde, P. Dilks, S. Heber, T. E. Steeves, M. Walters, S. Shaw, J. Potter, M. Farrant, D. H. Brunton, M. Hauber, B. Jackson, P. Bell, R. Moorhouse, K. McInnes, and A. Varsani. Molecular characterisation of beak and feather disease virus (BFDV) in New Zealand and its implications for managing an infectious disease. Arch. Virol. 157:1651-1663. 2012.

33. Müller, H., and R. Nitschke. A polyoma-like virus associated with an acute disease of fledgling budgerigars (Melopsittacus undulatus). Med. Microbiol. Immun. 175:1-13. 1986.

34. Ortiz-Catedral, L., K. McInnes, M. E. Hauber, and D. H. Brunton. First report of beak and feather disease virus (BFDV) in wild red-fronted parakeets (Cyanoramphus novaezelandiae) in New Zealand. EMU 109: 244-247. 2009.

35. Palinauskas, V., V. Kosarev, A. Shapoval, S. Bensch, and G. Valkiunas. Comparison of mitochondrial cytochrome $b$ lineages and morphospecies of two avian malaria parasites of the subgenera Haemamoeba and Giovannolaia (Haemosporida : Plasmodiidae). Zootaxa. 1626:39-50. 2007.

36. Pass, D. A., and R. A. Perry. The pathology of beak and feather disease. Aust. Vet. J. 61:69-74. 1984.

37. Phalen, D. N., V. G. Wilson, and D. L. Graham. Polymerase chain reaction assay for avian polyomavirus. J. Clin. Microbiol. 29:1030-1037. 1991.

38. Phalen, D. N., B. G. Wilson, and D. L. Graham. Production of avian polyomavirus seronegative budgerigars (Melopsittacus undulatus) from seropositive adults. Avian Dis. 39:897-899. 1995.

39. $\mathrm{R}$ Core Development Team. A language and environment for statistical computing. Foundation for Statistical Computing, Vienna, Austria. 2012.

40. Raidal, S. R., C. L. McElnea, and G. M. Cross. Seroprevalence of psittacine beak and feather disease in wild psittacine birds in New South Wales. Aust. Vet. J. 70:137-139. 1993.

41. Ritchie, B. W. Avian viruses: function and control. Wingers Publishing, Florida, USA. 1995.

42. Ritchie, B. W., K. S. Latimer, D. Pesti, R. Campagnoli, and P. D. Lukert. Vaccination to control polyomavirus in budgerigars. In: Proceedings-Association of Avian Veterinarians, Reno, NV. pp. 237-245. 1997.
43. Ritchie, B. W., F. D. Niagro, K. S. Latimer, J. Vernot, D. Pesti, R. P. Campagnoli, and P. D. Lukert. Polyomavirus infections in adult psittacine birds. J. Assoc. Avian Vet. 5:202-206. 1991.

44. Ritchie, B. W., F. D. Niagro, P. D. Lukert, W. L. Steffens, and K. S. Latimer. Characterization of a new virus from cockatoos with psittacine beak and feather disease. Virology 171:83-88. 1989.

45. Ritchie, P. A., I. L. Anderson, and D. M. Lambert. Evidence for specificity of psittacine beak and feather disease viruses among avian hosts. Virology 306:109-115. 2003.

46. Ronquist, F., and J. P. Huesenbeck. MRBAYES 3: Bayesian phylogenetic inference under mixed models. Bioinformatics 19:15721574. 2003.

47. Rott, O., M. Kröger, H. Müller, and G. Hobom. The genome of budgerigar fledgling disease virus, an avian polyomavirus. Virology 165: 74-86. 1988.

48. Sturrock, H. J. W., and D. M. Tompkins. Avian malaria parasites (Plasmodium spp.) in Dunedin and on the Otago Peninsula, southern New Zealand. N. Z. J. Ecol. 32:98-102. 2008.

49. Swofford, D. L. PAUP*: Phylogenetic analysis using parsimony (and other methods) 4.0 Beta, Version 10. Sinauer, Sunderland, MA. 2002.

50. Tompkins, D. M., and D. M. Gleeson. Relationship between avian malaria distribution and an exotic invasive mosquito in New Zealand. J. R. Soc. N. Z. 36:51-62. 2006.

51. Valkiūnas, G. Avian malaria parasites and other haemosporidia. CRC Press, Boca Raton, FL. 2004.

52. Waldenström, J., S. Bensch, D. Hasselquist, and O. Ostman. A new nested polymerase chain reaction method very efficient in detecting Plasmodium and Haemoproteus infections from avian blood. J. Parasitol. 90:191-194. 2004

53. Warburton, L. S., and M. R. Perrin. PBFDV bei frei lebenden Rukópfchen in Sambia. Papageien 5:166-169. 2002.

54. Worthington, B. Import risk analysis: Psittacine hatching eggs. In: MAF Biosecurity New Zealand, Pastoral House, Wellington, New Zealand. 2010.

\section{ACKNOWLEDGMENTS}

This study was made possible through the financial support of the Wildlife Disease Association Australasian chapter, the University of Queensland Teaching and Learning Committee, Massey University, Ecosure Environmental Consultancy, Topflite New Zealand Ltd., and The Federation of Cage Bird Clubs New Zealand. Special thanks must go to those budgerigar fanciers who made their birds available for sampling, Sheryl Baron for assisting with sample collection, Ristan Greer at the University of Queensland, and Ben Stevenson at the University of St. Andrews for the epidemiological and statistical support and to the staff at the Institute for Veterinary, Animal, and Biomedical Sciences (Massey University) for their technical support. 